\title{
EMPLOYMENT RIGHTS IN AN ERA OF INDIVIDUALISED EMPLOYMENT
}

\author{
Gordon Anderson*
}

On 7 August 2007, Gordon Anderson delivered his inaugural lecture after becoming a professor in the Law Faculty of Victoria University of Wellington. Gordon took as his theme the protection of employees employed on an individual contract of employment. Following the repeal of the award system by the Employment Contracts Act 1991 the majority of New Zealand employees ceased to be covered by collectively negotiated instruments. Instead the contract of employment became dominant. The lecture argued that the common law contract of employment provides little protection for employees. Instead protection depends on some critical statutory interventions that provide a degree of balance within the employment relationship. While not perfect, these protections may be the best that can be expected in the real world of employment.

It is a great privilege to be able to address such a distinguished audience this evening. This is particularly so if you are one of those who recalls the warning of one former Minister of Labour that my "assertions stray into the domain of the wild and erratic." ${ }^{1}$ It is also a privilege to give this lecture in a university with a strong tradition of scholarship in labour law and industrial relations.

As early as 1941 the University appointed AEC Hare as the fellow in "social relations in industry". Rachel Barrowman reports that although Hare published a significant study, Industrial Relations in New Zealand: ${ }^{2}$

Employers thought he was a stooge of the Labour government, while trade unions were suspicious of the university; the Department of Labour was resentful and obstructive, seeing the very fact of his investigation as implied criticism. He was subject to personal attacks in the press and Parliament ${ }^{3}$

* Professor of Law, Victoria University of Wellington. This paper has been slightly modified from the lecture, mainly by the addition of footnotes and references.

1 Honourable W F Birch, Minister of Labour "Correspondence" [1992] ELB 7.

2 AEC Hare Report on Industrial Relations in New Zealand (Victoria University of Wellington, Wellington, 1946)

3 Rachel Barrowman Victoria University of Wellington 1899 - 1999 A History (Victoria University Press, Wellington, 1999) 64. 
The study of what was then industrial law was established at Victoria by two distinguished scholars, Professors Don Mathieson and Alexander Szakats. ${ }^{4}$

While Professor Mathieson departed academia at a relatively early age for a career at the bar Professor Szakats followed the opposite path. Commencing his academic career at a relatively late age of 50 the redoubtable Professor Szakats produced his major work in his 60s and early 70s. ${ }^{5}$

I would also like to acknowledge the staff of the Industrial Relations Centre, ${ }^{6}$ with whom I worked closely for many years. In its heyday this Centre was the incubator for a generation of leading academics of whom two I worked closely with are here this evening - Professor Pat Walsh and Professor Peter Brosnan. ${ }^{7}$ The Centre provided the catalyst for an enviable range of scholarship and made a significant contribution to policy debate through the turbulent years from the 1970s to the 1990 s.

I also acknowledge my debt to two of my academic collaborators and colleagues, John Hughes of the Law School at the University of Canterbury, my own alma mater, and Paul Roth at Otago. ${ }^{8}$

\section{THE MODERN EMPLOYMENT RELATIONSHIP}

This evening's lecture is entitled "Employment Rights in an Era of Individualised Employment". The theme I wish to address is whether current employment law adequately protects the legitimate employment expectations of employees employed in an individual employment relationship.

I first discuss what employee expectations might be. I then turn to the role of the common law contract of employment, the contract that is central to an individual employment relationship. Finally I consider how statutory interventions, most notably personal grievance rights and the duty of good faith, have impacted on the employment relationship.

4 The major texts by each were D L Mathieson Industrial Law in New Zealand (Sweet and Maxwell, Wellington, 1970) and A Szakats Law of Employment (Butterworths, Wellington, 1975). Professor Szakats was also, for 15 years, the editor of what was then entitled Mazengarb's Industrial Relations and Industrial Law in New Zealand (looseleaf, Butterworths, Wellington).

5 Professor Szakats died in 2001. For an obituary see Martin Vrankin "Alexander (Sandor) Szakats: A Tribute" (2001) 32 VUWLR 627.

6 The Centre was established in 1970, its first Director being Professor FJL Young.

7 See for example G Anderson, P Brosnan and P Walsh "Flexibility, Casualization and Externalization in the New Zealand Workforce" (1994) 36 Journal of Industrial Relations 491. Professor Walsh is currently ViceChancellor at Victoria University of Wellington. Emeritus Professor Brosnan retired as Professor of Industrial Relations at Griffith University in 2004.

8 This collaboration particularly relates to Mazengarb's Employment Law (looseleaf, LexisNexis, Wellington) 5 volumes [Mazengarb] and Personal Grievances (looseleaf, LexisNexis, Wellington). 
As I hope will become apparent the common law has been reluctant to recognise anything other than a minimal employee stake in employment. Wider recognition has almost always required legislative intervention.

The answer to the question "why do people work?" is fairly obvious. The more relevant question is whether those members of society who must sell their time, effort or skill in return for a wage or salary have legitimate employment-based expectations that are deserving of legal protection? Historically employment law has more than adequately met the expectations of employers. It continues to do so. What it has not done until recently is balance the expectations of employers with those of employees.

In the real world employers must build stable and skilled workforces and to do so must make considerable investments in recruitment and training. They must find labour in real labour markets and must adjust to the reality that valuable employees will take advantage of such markets. There is probably no ideal world where employers can find a pool of appropriately skilled labour available at the lowest possible price and where they can unilaterally control a loyal labour force and unilaterally dismiss it. Somewhere between these worlds however there developed a set of values based around strong property rights and a commodity oriented view of labour. It is a perspective with deep historical roots, reinforced by economists and accountants, and it has strongly influenced the law.

Employees have a different perspective. Employees may work for a wage but do not expect to be treated as commodities. They expect to be treated with regard for their safety and health and for recognition to be given to their economic security and to the investment they make in employment. They expect to participate in determining their conditions of employment, to be involved in workplace governance, and to be consulted if their economic future is threatened. Democratic values and democratic citizenship are incompatible with the belief that labour is a commodity.

An employment relationship in a modern democratic society needs to recognise that employees, as well as employers, take risks in an employment relationship and that the simplistic propertycontract divide of the common law cannot adequately regulate long term relationships where both parties make a significant investment. ${ }^{9}$

In an employment relationship each party risks the other engaging in opportunistic behaviour. Employers may find that employees fail to demonstrate their claimed competence or that they jeopardise the employers' proprietary information. Employees risk pre-employment promises not equating to post-employment realities or their personal and economic security being compromised by incompetent management or unjustifiable decisions.

$9 \quad$ For a union perspective on this point see Andrew Little "Employment Risk: Whose is it?" (speech to the Institute of Directors, Northern Branch, 27 July 2006) available at www.epmu.org.nz (accessed 14 August 2007). 
And increasingly a significant risk faced by employees is the risk to their educational, reputational and intellectual capital, often developed at considerable financial cost before and increasingly during employment. An employee dismissed without credible justification may find their reputation compromised, their educational qualifications devalued, and their employability undermined.

Finally, every employment relationship must look to that third force inserting itself into the fissures of the relationship. Every form of labour market from slavery to the modern employment relationship requires the support and authority of the state. Since time immemorial, or at least shortly thereafter, the English state has attempted to legislate to control labour markets. ${ }^{10}$

In modern societies it is inevitable that employment relationships are tripartite. State interventions are a response to political and economic pressures and reflect the investment and the liabilities of the social democratic state. The state educates and trains much of the labour force. The state supports those who have fallen out of the active labour force - whether through injury, dismissal or retirement. And the state ensures industrial peace and limits the potential social and economic harm that can result from unstable industrial relations.

The dilemma that these competing interests pose for labour law was summarised by Hugh Collins: ${ }^{11}$

Employment law ... regulates employment relations for two principal purposes: to ensure that they function successfully as market transactions, and at the same time, to protect workers against the economic logic of the commodification of labour.

Collins makes the point that any resolution of this dilemma will be complex and contested, a point abundantly demonstrated by the often intemperate debate in New Zealand over the last three decades.

\section{THE CHANGING ENVIRONMENT}

When I first arrived at this University three decades ago a lecture on individual employment would have consisted of little more than an uninteresting summary of some English common law rules and that perennial legal favourite - who is a "worker"? We had better things to discuss. It was the heyday of the Muldoon government's anti-union campaign.

So what changed in the last three decades?

One change has been a burgeoning of scholarship triggered by the growth of non-union, individualised employment and by the enactment of statutory protections for individual employees,

10 Systematic attempts can be dated from the Ordinance of Labourers 1349.

11 Hugh Collins Employment Law (Oxford University Press, Oxford, 2003) 5. 
most notably against unfair dismissal. I will mention only a few recent contributions as illustrative of a generation of scholarship. One is the original and extensive analysis of the modern contract of employment in Professor Mark Freedland's book The Personal Employment Contract. ${ }^{12}$ A second is Professor Simon Deakin and Dr Frank Wilkinson's analysis of the historical origins and nature of the modern employment relationship in The Law of the Labour Market. ${ }^{13}$ Outside Britain contributions include Dr Joellen Riley's recent book Employee Protection at Common Law ${ }^{14}$ examining the law in an Australian context, the work of Professor Katherine Stone in the United States on the evolution of employment relationships in modern economies ${ }^{15}$ and that of Professor Judy Fudge in Canada. ${ }^{16}$

This body of scholarship is characterised by its strong historical, industrial relations, economic and political perspective. The reasons for a multi-disciplinary focus were made clear by a pioneer of labour law scholarship. Professor Otto Kahn-Freund commenced his 1972 Hamlyn Lectures, Labour and the Law, with the statement that "Labour law is a technique for the regulation of social power". ${ }^{17}$ He went on to make the point that while the law might support, restrain and even create power, the law itself is not the source of social power.

Kahn-Freund recognised that in the workplace social and economic power manifests itself obviously and directly. He argued that the principal function of labour law is to act as a countervailing force to counteract the inequality of bargaining power inherent in the employment relationship. ${ }^{18}$

The practical reality of social power became increasingly manifest over the last three decades as the result of a fundamental realignment of economic and political power within the labour market. Changing patterns of employment led to a significant drop in union density, and hence collective bargaining. Individualised employment has become increasingly dominant. In the United Kingdom,

12 Mark Freedland The Personal Employment Contract (Oxford University Press, Oxford, 2003).

13 Simon Deakin and Frank Wilkinson The Law of the Labour Market: Industrialization, Employment and Legal Evolution (Oxford University Press, Oxford, 2005).

14 Joellen Riley Employee Protection at Common Law (The Federation Press, Sydney, 2005).

15 Katherine Stone From Widgets to Digits: Employment Regulation for the Changing Workplace (Cambridge University Press, Cambridge, 2004)

16 See for example Judy Fudge "The Spectre of Addis in Contracts of Employment in Canada and the UK" (2007) 36 ILJ 51. This issue of the ILJ (Issue 1) contain a series of articles discussing the contract of employment.

17 Otto Kahn-Freund Labour and the Law (Stevens, London, 1972) 4.

18 Ibid 8. 
Australia and New Zealand, this trend was exacerbated by a political environment openly hostile to trade unions and collective bargaining. ${ }^{19}$

The effects were spectacular in New Zealand. In the mid-1980s, towards the end of the arbitration era, probably two-thirds of employees were covered by some form of collectively negotiated instrument, be it an award or its public sector equivalent. ${ }^{20}$ The Employment Contracts Act 1991 changed that picture rapidly and dramatically. Today, after seven years of a supposedly union-friendly Act, collective agreements cover only 20 percent of workers and just 9 percent in the private sector. There has been a total reversal of the situation of two decades ago. ${ }^{21}$ Today 80 percent of New Zealand employees are employed wholly on individual contracts of employment.

It is useful to recall two fundamental protections provided by the award system and to consider whether contemporary law is able to provide equivalent protection. First, the system ensured that detailed conditions of employment - remuneration, hours of work, rest periods, sick leave and so on - were determined collectively. Today protections once provided by agreement have typically been displaced by open-ended, employer discretions, often having limited legal force. The second protection was an effective voice in the administration of the employment relationship. Whatever the failings of compulsory union membership it provided rapid access to union expertise that limited potential managerial opportunism and promoted the effective enforcement of the legal rights of employees.

\section{CONTRACTUAL EMPLOYMENT}

In 1991 the deluge of the Employment Contracts Act swept away the few regulated trees that had escaped the Labour chainsaw, most obviously the arbitration system. Exposed by the flood were the contractual roots of employment long concealed by the forest of arbitration. ${ }^{22}$ But roots, seen in the distance through dark blue glasses, can be misleading.

19 For a discussion of developments in all three countries see Stephen Deery and Richard Mitchell (eds) Employment Relations: Individualisation and Union Exclusion. An International Study (Federation Press, Melbourne, 1999).

20 Harbridge and Hince estimated union density at 73 per cent in 1989. That figure under-represents bargaining coverage as that depended on being within the coverage clause of an award, not on union membership. Raymond Harbridge and Kevin Hince "Organising Workers: The Effect of the Act on Union Membership and Organisation" in Raymond Harbridge (ed) Employment Contracts New Zealand Experiences (Victoria University Press, Wellington, 1993) 224, 228.

21 Leda Blackwood, Goldie Feinburg-Danieli, George Lafferty and Peter Kiely Employment Agreements: Bargaining Trends and Employment Law Update 2005/2006 (Industrial Relations Centre, Victoria University of Wellington, Wellington, 2006) 16-17.

22 Legally all employees entered into a contract of employment but in practice it was rendered largely irrelevant due to the detailed nature of awards. Awards were a statutory instrument and enforceable as such. 
The more extreme proponents of labour market reform had a simple vision of what should replace the award system - the law of contract. Central to new-right's mythical chimera of "freedom of contract" was the belief that workers are a commodity. "While people are not commodities", they argue, "the labour services they provide ... most certainly are", ${ }^{23}$ a theoretical separation likely to appeal only to Chicago economists and Cartesian dualists.

Roger Kerr of the Business Roundtable summed up the desired new order: ${ }^{24}$

The conclusion reached in New Zealand by many business and employer organisations, government

officials and the government which was elected in December 1990 was that employment relationships

should, by and large, be regulated by ordinary contract law.

However as Kerr realised, and condemned, the ECA did not introduce the pure contractual model. ${ }^{25}$ The minimum wage was not abolished, health and safety requirements were not left to be negotiated by individual contracts. Discrimination law was not repealed to allow the market to promote equality more effectively - something it had failed to achieve over many years before the 1970s.

And to the particular chagrin of the new-right, protection from unjustified dismissal was not only retained but extended to all employees.

It is hardly surprising that the simplistic contractual model of neo-classical theory was not imposed. To have done so would have been politically untenable even in 1991. Instead the government focused on the more pragmatic strategy of de-unionising and individualising employment relationships. ${ }^{26}$

The contract of employment, instead of being largely the gateway to award coverage, became the legal heart of the employment relationship. The contract of employment is not however a simplistic classical contract. It is a highly sophisticated and developed legal instrument.

In A Theory of Employment Systems, David Marsden suggests that the rise of the modern business enterprise is based on two great innovations. ${ }^{27}$ The significance of the first, limited liability for companies, is generally well understood. The role played by the second innovation, the

23 Roger Kerr "Successes and Failures of Labour Market Reform in New Zealand" (paper delivered to Dublin Economic Workshop, 16 October 1999) 5, available at www.nzbr.org.nz (accessed 14 August 2007).

24 Ibid 6-7.

25 Ibid 9-10.

26 See Gordon Anderson "Individualising the Employment Relationship in New Zealand: An Analysis of Legal Developments" in Deery and Mitchell, above n 19.

27 David Marsden A Theory of Employment Systems: Microfoundations of Societal Diversity (Oxford University Press, Oxford, 1999) 3. 
employment relationship, or more accurately in legal terms, the contract of employment, much less so.

To appreciate its importance it is necessary to consider the legal context in 1875. In that year the British Parliament repealed two pillars that had dominated labour law since the eighteenth century, the Master and Servants Act and the law of criminal conspiracy as it applied to trade disputes. Before 1875 the discipline of labour was ensured through the use of coercive criminal sanctions. ${ }^{28}$ Moves towards genuine parliamentary democracy and universal suffrage, together with the increasing influence of trade unions, meant that a system based on criminal law ceased to be tenable.

It was to filling the resultant lacunae that the common law judges turned their inventive, if not disinterested, minds. Developing a two part strategy they sought to ensure the natural order continued to prevail. The law of tort was rapidly evolved to deploy against collective activity. As the Webbs put it "what could no longer be punished by imprisonment might at any rate be penalised by heavy damages and costs." ${ }^{29}$ Fortunately the Industrial Conciliation and Arbitration Act 1894 largely spared New Zealand the industrial and political fallout from these developments. ${ }^{30}$

The second creation was the contract of employment - essentially the reformulation of the long established common law rules of master and servant in contractual guise. Deakin and Wilkinson describe the process as "the assimilation by the common law of a hierarchical, disciplinary model of service". 31

This innovation was remarkably successful for two quite different reasons.

First, it provided the legal vehicle to ensure the perpetuation of ownership control of labour. In particular it provided the limited liability company, itself an innovation of the mid-nineteenth century, a flexible method for coordinating work within an entity based on a hierarchical

28 For a detailed account of the origins and development of employment law see Deakin and Wilkinson, above n 13, part 2, 41 "The Origins of the Contract of Employment". In many Commonwealth countries master and servants acts remained important well into the last century: see Douglas Hay and Paul Craven (eds) Masters, Servants, and Magistrates in Britain and the Empire, 1562-1955 (Chapel Hill, University of North Carolina Press, 2004). The Acts seem to have had little impact in New Zealand but see Herbert Roth "The Historical Framework" in John Deeks and others (eds) Industrial Relations in New Zealand (Methuen, Wellington, 1978) 21-22 for some examples from the 1840s.

29 Sidney and Beatrice Webb The History of Trade Unionism 1666-1943 (S\&B Webb, Edinburgh, 1920$) 597$. The conflict was resolved by the Trade Disputes Act 1906 (UK).

30 The economic torts briefly reared their head in the 1970s and 1980s: see Gordon Anderson "The Reception of the Economic Torts into New Zealand Labour Law: A Preliminary Discussion" (1987) 12 NZJIR 89. The Labour Relations Act 1987 defined a "lawful" strike for the first time. Since that reform a common law action in tort is only available if a strike is not lawful.

31 Deakin and Wilkinson, above n 13, 107. 
management structure and a centrally directed, vertically integrated production mode. The indeterminate nature of the contract allowed an employer to build a stable but flexible labour force available to work as required on changing tasks. The practical success of the contract of employment resulted in a largely homogenous form of employment. From about the end of the First World War this provided governments with a legal mechanism through which they could increasingly link the protections and demands of the modern social democratic state to the workplace and to the individual employee. This process further encouraged a common form of employment status - the modern "employee". ${ }^{32}$

To return to 1875 . The common law judges faced a dilemma summarised by Alan Fox. ${ }^{33}$

Since no employment contract could anticipate all relevant contingencies ... the damaging implication of pure contract for the employer would have been that it could not allow him to be the sole judge of whether his rules were arbitrary or exceed the scope of his authority ... It followed that contract as the pure doctrine defined it could not be seen by the property-owning classes as an adequate foundation for governing the employment relation.

The common law responded by developing a legal template that automatically embedded the interests of the employing entity at the point the contract was entered into. Fully developed this template allows an employment contract to be agreed on only the most minimal terms - essentially a wage and a basic job description. The other elements required by the employer are already in place.

The contractual device used to achieve this was the implied term, which to quote one judge is "a term which the law will imply as a necessary incident of a definable category of contractual relationship". ${ }^{34}$ Such terms owes nothing to the agreement of the parties and everything to the judicial perspective of what is "necessary." The employee will often not even be aware of their existence let alone their implications.

I will briefly summarise the core terms to make their importance clear. ${ }^{35}$

First employees must obey all reasonable orders - essentially orders that fall within the employee's contractual obligations, usually broadly drafted by the employer, and which are not otherwise unlawful. This obligation can be surprisingly open-ended. In one English case school teachers were informed that they must perform any duties that the community might expect of

32 Ibid 105-109.

33 Alan Fox Beyond Contract, Work, Power and Trust Relations (Allen \& Unwin, London, 1974) 184.

34 Scally v Southern Health and Social Services Board [1991] 4 All ER 563, 571 (HL) Lord Bridge.

35 For a full account refer to Mazengarb above n 8, para 1019 and following. 
school teachers, a decision issued during a dispute where some of those duties were hotly contested. ${ }^{36}$

This term is central to the business enterprise. It allows an employing entity to employ labour on terms that give its management broad powers to direct and control the detailed nature of the work to be subsequently carried out without the need to renegotiate the nature of the task or the terms under which it will be carried out on each occasion. Obviously such a term minimises transaction costs and increases the efficient use of labour.

The second term is a duty of fidelity owed to the employer - a term carrying connotations of feudalism. This term fulfils two functions. It protects the employer's property, especially its proprietary information, by making it unlawful for an employee to use information gained in the course of employment for personal benefit.

The second function is more problematic. In essence it requires an employee to give preference to the employers' economic interests over their own if there is any potential for a conflict of interest. This is so even if that conflict arises from non-work activities. An employee is of course obliged to work in the interest of their employer where the work in question falls within their express obligations. As applied however the term severely limits an employee's ability to use their skills and expertise for their own economic benefit. Any conflict is almost inevitably resolved in favour of the employer. In a recent Australian case an academic, contractually entitled to perform personal work, was ordered to assign independently developed intellectual property to the employer purely because he could have chosen to develop that property for the employer - a decision effectively negating the specific contractual term. ${ }^{37}$

I am aware that not all implied terms benefit the employer. For example there is a term requiring the employer to provide a safe place of work that has assumed importance in recent cases involving stress. ${ }^{38}$ Of greater impact is the implied term of mutual trust and confidence, ${ }^{39}$ now a central component of the statutory duty of good faith. This term originated in Britain in the mid-1970s and was confirmed in New Zealand in the mid-1980s. ${ }^{40}$ Its unusual feature is that it developed in the context of statutory unfair dismissal law to provide the courts with a contractual basis for constructive dismissals. Over three decades this term has evolved to encompass a range of duties requiring the parties to a contract to desist from behaviours that might undermine the trust and

36 Sim v Rotherham Metropolitan District Council [1986] 3 All ER 387 (Ch).

37 Victoria University of Technology v Wilson [2004] VSC 33.

38 Attorney-General v Gilbert [2002] 2 NZLR 342 (CA).

39 For an analysis of the development of the law see Freedland above n 12, 154-168 and the references therein.

40 Auckland Shop Employees Union v Woolworths (NZ) Ltd [1985] 2 NZLR 372 (CA) and Marlborough Harbour Board v Goulden [1985] 2 NZLR 378 (CA). 
confidence each should have in the other. However given the wealth of pre-existing terms binding employees its main impact has been to constrain employer behaviours.

Significantly however the courts have refused to apply this term to constrain an employers' most devastating common law power - the power to dismiss without reason. ${ }^{41}$

The power to dismiss without reason and without consequences was the second common law device used to cement the pre-eminence position of the employer. Lord Reid summarised the law thus: "At common law a master is not bound to hear his servant before he dismisses him. He can act unreasonably or capriciously if he chooses but the dismissal is valid." 42

Unless there is serious misconduct the employer must give the contractual period of notice - but historically only a tiny minority of managerial level employees have been entitled to other than token notice. For most employees their employment security was effectively at the immediate will of the employer. Employees who challenged management or sought to assert their own rights, no matter how legitimately, had no remedy. No matter how egregious, discriminatory, or irrational the employer's decision prevailed. And regardless of the reputational and economic consequences of the dismissal, or the manner in which it was carried out, and no matter how foreseeable the loss, the employee had no legal remedy. Reinforcing this position, in 1909 in Addis ${ }^{43}$ the House of Lords held that damages can only be awarded where contractual notice is not given and that damages may not exceed the remuneration payable during the notice period. ${ }^{44}$

Kahn-Freund summarised the nature of the contract of employment in the following terms: ${ }^{45}$

In its inception it is an act of submission, in its operation it is condition of subordination, however much that submission and subordination may be concealed by that indispensable figment of the legal mind known as the 'contract of employment'.

\section{STATUTORY INTERVENTIONS}

In the real world of course employees are unimpressed with the ahistorical formalism with which the common law surrounds the employment relationship. They use their political influence, collectively and individually, to obtain a degree of countervailing power. Employees generally, and those who depend on them, make up the majority of the general public and they know when employment law is unjust. The political use of that countervailing influence has had significant implications for the character of the employment contract created by the common law.

41 Air New Zealand v Raddock [1999] 1 ERNZ 30, 36 (CA) Henry J for the Court.

42 Malloch v Aberdeen Corporation [1971] 1 WLR 1578, 1581 (HL) Lord Reid.

43 Addis v Gramophone Co Ltd [1909] AC 488 (HL).

44 For a discussion of the importance of this case see Freedland above n 12, 356 and following.

45 Khan-Freund, above n 17, 8. 
Legislative drafters have used the status of "employee" as a gateway to deliver a variety of legal rights and obligations which in turn have reshaped the legal architecture of the employment relationship. I note in passing, as there is no time to develop this theme, that this legislative technique positioned the judiciary as the gatekeepers to such rights. Deciding who is or is not an employee has provided decades of amusement for judges and fees for lawyers. ${ }^{46}$

There are broadly two, albeit overlapping, generations of statutory intervention.

The first generation created a statutory floor of employment rights - the requirement to pay wages as money, the minimum wage and guaranteed public and annual holidays. ${ }^{47}$ More recently this has extended to specific social and human rights - protection against discrimination, the right to parental leave ${ }^{48}$ and the right of freedom of association and to bargain collectively. ${ }^{49}$ These first generation interventions did not however significantly impinge on the managerial prerogatives and powers conceded by the common law and I will not discuss them further.

Second generation interventions however go directly to the heart of so-called management prerogatives and the claimed right of an employing entity "to run its business as it thinks fit". ${ }^{50}$ Such interventions are typified by unfair dismissal laws.

Something of the traditional common law spirit remains however. Legislation is interpreted by courts who may be less than sympathetic to the aims of the reform. Indeed periodic skirmishes between courts and legislatures over the direction of the law seems to be a defining characteristic of labour law in most common law jurisdictions. It is a factor that should strongly focus the legislative mind. ${ }^{51}$

46 For a discussion of the complexity and volume of the case law see Mazengarb above $\mathrm{n}$ 8, paras ERA6.2ERA6.19.

47 Wages Protection Act 1983 [1891], Minimum Wage Act 1983 [1936], Holidays Act 2003 [1910]. The dates in square brackets in this and the following note are the year legislation on that subject was first enacted. Some additional protections were afforded through the arbitration system, for example the presumption of a 5 day, 40 hour week (Labour Relations Act 1987, s 172).

48 Human Rights Act 1993 [1971], Parental Leave and Employment Protection Act 1987 [1980].

49 The legal right to organise in unions has existed since 1878 (Trade Unions Act) but the right to bargain collectively in its modern sense evolved more slowly out of the arbitration system. A clear statutory right to strike was first enacted in the Labour Relations Act 1987, s 233.

50 Aoraki Corporation Ltd v McGavin [1998] 1 ERNZ 601, 618 (CA) Judgment of the Court.

51 Compare the majority and dissenting judgments in Coutts Cars Ltd v Baguley [2001] 1 ERNZ 660 (CA) for an example of this. 


\section{A Second Generation Interventions}

For the final part of this lecture I turn to the two major second generation legislative developments constraining an employing entity's unilateral decision making power. The first was the personal grievance procedures introduced in 1973 and extended to cover all employees in $1991 .{ }^{52}$ The second is the duty of good faith which forms a fundamental plank of the Employment Relations Act 2000.

\section{Personal grievances}

To turn first to personal grievances. Their most fundamental feature is that they require an employing entity to justify a decision to dismiss an employee. It is not for the employee to demonstrate that the employer lacked justification. The employer has a positive obligation to demonstrate both substantive reasons for the dismissal and that it was carried out in a manner that accords with natural justice. Moreover if a dismissal is found to be unjustified the employer will be liable to pay compensation for lost remuneration, for other economic loss and for the humiliation and loss of dignity caused to the employee.

Personal grievance rights displace the common law assumptions that an employer is the sole judge of whether or not to dismiss an employee and that the employer cannot be liable for the financial consequences that a dismissal may visit on the employee.

These rights represent a fundamental shift in attitudes to employment. An employee is no longer a commodity but a person who has the right to fair treatment, a person who should not be deprived of their economic security and the investment in their employment without justifiable reasons and then only if the principles of natural justice are observed.

However effective protection is dependent on two factors - the standard of justification and the effectiveness of the remedies available. Both have proved to be contentious since 1991. The retention of personal grievance rights in 1991 was particularly controversial. New Right lobby groups had demanded their repeal. This disappointment manifested itself in a vehement, sustained and wholly unjustifiable attack on the Employment Court judges, alleging they were proemployee. ${ }^{53}$ Despite the best efforts of the New Right, and detailed analysis of the Court's decisions, no evidence was produced to justify these assertions. ${ }^{54}$

52 For a discussion of the origins of the procedures see Gordon Anderson "The Origins and Development of the Personal Grievance Procedure in New Zealand" (1988) 13 NZJIR 257.

53 See Gordon Anderson "The Judiciary, the Court and Appeals" [1993] ELB 90 and "Politics, the Judiciary and the Court - Again" [1995] ELB 2.

54 See for example the Treasury commissioned study: J Hodder and J Foster The Employment Contracts Act: The Judicial Influence 1991-1997 (Institute of Policy Studies, Wellington, 1998) and my review of that book in [1999] ELB 46. 
This attack may, nevertheless, have had the desired effect in influencing the judicial climate. During the 1990s the Court of Appeal took an increasingly conservative approach to the law. Even though the substantive provisions were largely untouched, the Court, in Aoraki, opined that "the context in which they operate is sharply changed by the emphasis in the 1991 Act on contractual freedom." ${ }^{55}$ Before that point the test of justification had been largely objective with the employer's decision reviewed against a notional reasonable employer who had taken account of all relevant matters including the position of the employee.

The Court shifted this focus to give greater weight to the employer perspective, making it essentially a more subjective test. ${ }^{56}$ It held it was not the function of the courts to substitute their view for that of the employer. It also allowed employers considerable discretionary latitude. If dismissal fell within a broad range of responses open to the employer the dismissal was justified even if a court, essentially the neutral observer, might regard it as unduly harsh.

As Paul Roth has pointed out, the problem with such a one-sided approach is that it uses as the measure of fairness the perspective of the class of persons whose conduct the legislation was intended to regulate. ${ }^{57}$ Effective protection requires that the employer is not the judge of the reasonableness of its own actions. Those actions must be tested in a neutral forum against an objective standard.

This reactionary trend was reversed by section 103A of the Employment Relations Act. Justification is again determined on an objective basis, by considering whether the employer's actions were what a fair and reasonable employer would have done in all the circumstances. Judge Shaw has summarised its effect as restoring to the courts "the duty of inquiry and the right of judgment". 58 She added: 59

It may mean that the Court reaches a different conclusion from that of the employer but, provided this is done appropriately, that is objectively and with regard to all the circumstances at the time the dismissal occurred, a conclusion different from that of the employer may be a proper outcome.

55 Aoraki Corporation Ltd v McGavin, above n 50, 612 Judgment of the Court.

56 For an account of the evolution of the test see Mazengarb above n 8, paras ERA103A.6-ERA103A.7.

57 Paul Roth "The Poverty of Fairness in Employment Law" [2001] ELB 85

58 Air New Zealand Ltd v Hudson [2006] 3 NZELR 155, para 120 (EC) Judge Shaw.

59 Ibid. 
I noted above that effective protection requires effective remedies. The Court of Appeal has also kept a firm hand on the quantum of compensation. This has not been without criticism and a case can be made that compensation might be considerably more generous. ${ }^{60}$

\section{The duty of good faith}

The second important legislative development is of the duty of good faith introduced in $2000 .{ }^{61}$ This duty potentially it goes to the heart of the individual employment relationship and to management prerogative.

It requires the parties to an employment relationship to "be active and constructive in establishing and maintaining a productive employment relationship in ... which the parties are responsive and communicative." It applies to "any matter arising in relation to an individual employment agreement". ${ }^{62}$ It permeates all aspects of every employment relationship.

For individual employees the most obvious requirement is that they be consulted on business proposals that might impact on their future employment. This requirement overrules a line Court of Appeal decisions holding that an employer was not obligated to consult employees on commercial decisions - only to implement them in a fair manner. In Aoraki the Court stated: "To impose [a] requirement of that kind would be inconsistent with the employer's prima facie right to organise and run its business operation as it sees fit."63

The new duty to consult was not received enthusiastically by that Court, the majority resisting submissions that the Act required a re-evaluation of the law. It required the recasting of the provisions in 2004 to make the intended changes unequivocally clear. ${ }^{64}$

Consult is not merely a synonym for "tell". ${ }^{65}$ Employers must involve employees during the development of a proposal, provide relevant information, allow sufficient time for a developed response, and properly consider that response. Failure to consult carries significant legal risk. The courts may delay the implementation of redundancies until proper consultation has occurred. If a dismissal is challenged failure to consult may lead to substantial compensation being awarded and

60 See further Gordon Anderson "Reimbursement and Compensation for Unjustified Dismissal" (2006) 12 NZBLQ 230, 249-251.

61 See generally Gordon Anderson "Transplanting and Growing Good Faith in New Zealand Labour Law" (2006) AJLL 1.

62 Employment Relations Act 2000, s 4.

63 Aoraki Corporation Ltd v McGavin, above n 50, 618, judgment of the Court.

64 Employment Relations Act 2000, s 4(1A) inserted by s 5(1) of the Employment Relations Amendment Act 2004.

65 Simpsons Farms Ltd v Aberhart [2006] 4 NZELR 170, paras 59-63 (EC) Chief Judge Colgan. 
throw doubt on the genuineness of the decision. The Employment Court has made it clear that a failure to consult will vitiate the dismissal. A fair and reasonable employer, held Chief Judge Colgan, is one that complies with its legal obligations. ${ }^{66}$ The employer remains free to make the final decision but its employees are entitled to a be properly heard as such decisions may impact on their employment security.

As I have already described, the common law expects a very high standard of conduct from employees, and indeed the statutory duty of good faith confirms and reinforces this expectation. In the case of employers the law has been somewhat more flexible. The second issue I would like to consider is whether the duty of good faith affects the standard of conduct expected of employers. In 1992 the Court of Appeal held that the implied term of fair treatment does not require an employer to conform at all times to the highest standards of good management practice. ${ }^{67}$ The Court commented that this "would be an unlikely obligation for any employer to accept, and it is certainly not one which could be implied into terms of employment." The Court conceded there was "much good sense" in expert evidence on good practice and noted an increasing awareness of such matters.

I suggest that the duty of good faith, especially as it was reformulated in 2004, requires the courts to take a more proactive approach and to require employers to act in accordance with at least contemporary standards of good management practice and in some cases with best standards. I further suggest that many of the more intractable problems being identified in the modern workplace can only be dealt with by requiring such a standard. Managing the negative consequences of the new "flexible" workplace - excessive workloads, the psychological and physical consequences of stress and workplace bullying - requires high standards of management competence. The failure to effectively manage such issues poses a significant risk to employees and considerable legal risk for employers. Cases involving serious stress affecting an employee's long term employability have resulted in very high levels of damages. ${ }^{68}$

Good, and where appropriate best, management practice is now both a realistic expectation and an achievable standard The legal risk associated with personal grievances including discrimination and sexual harassment has required employers to be proactive in minimising risks. Arguably the most important benefit of such risk was the development of robust employment practices and standards by experts such as organisational psychologists and human resource practitioners. Properly used these provide important protections for both employers and employees. ${ }^{69}$ They are not perfect, and not always used appropriately, but they do exist. Problems such as poor

66 Ibid, para 65 Chief Judge Colgan.

67 Anderson v Attorney-General (23 October 1992) CA 292/91.

68

Attorney-General v Gilbert [2002] 2 NZLR 342 (CA).

69 See further Gordon Anderson and Jane Bryson "Developing the Statutory Obligation of Good Faith in Employment Law: What Might Human Resource Management Contribute?" (2006) 37 VUWLR 487. 
performance, misconduct and harassment are increasingly managed through processes designed to protect the interests of all parties.

These standards provide a solid foundation of theory and practice from which the courts might derive standards and expectations of good management practice. Equally importantly the courts should expect employers to be aware of good employment practice and to implement it. The Employment Court once commented: "This is a case about process and who controls it. It well illustrates the aphorism that procedure is power in employment relations". It noted the significant advantages an employer possesses through its control of process which the Court said is "the practical manifestation of 'the inherent inequality of bargaining power in employment relationships'" that is referred to in the objectives of the Employment Relations Act. ${ }^{70}$

This argument applies equally to employer control of human resources management processes. The statutory requirement that the parties be active and constructive in maintaining a good faith relationship reinforces arguments for the more active judicial review of management practices impacting on employees.

\section{CONCLUSION}

Collins commented that contemporary law "represents 200 years of the evolution of pragmatic attempts to balance the logic of the market system with the liberal aspiration to ensure that individuals are treated with respect and justly, and that they have the opportunity to construct meaningful lives." 71

I return to the question posed at the commencement of this lecture - does current law adequately protect the legitimate expectations of employees in an era of individual employment? I suggest that the answer is a qualified yes. Yes to the extent that is possible and defensible in the context of contemporary New Zealand society and politics. Yes for the majority of workers in most situations.

The two generations of statutory intervention I referred to provide an acceptable balance to the employer powers entrenched in the contract of employment and to the power of employers to dominate the express terms of such contracts. They provide the levers for governments and the courts to balance the conflicting interests of employers and employees while ensuring that the mutual benefits of their interaction are not lost. Both the personal grievance provisions and the duty of good faith are flexible and able to be applied in a common sense manner by an Authority and a Court that have a depth of experience in workplace relations. As always the courts must be prepared to use the available levers and in doing so they need to be fully mindful that employment relationships involve two parties, something that they do not always do.

70 New Zealand Amalgamated Engineering Printing \& Manufacturing Union Inc v Carter Holt Harvey Ltd [2002] 1 ERNZ 597, para 3 (EC) Judge Colgan.

71 Collins, above n 11, 5. 
The Employment Relations Act restored balance to the test of justification and the duty of good faith, a flexible and workable litmus test by which workplace behaviours can be evaluated. That Act provided New Zealand with perhaps the most flexible and non-bureaucratic employment law in the developed world - in spite of continuing claims that the Act is "employer-unfriendly" and "punishes business".

Margaret Wilson has commented that while legislation cannot change individual values or beliefs it can influence and change behaviours. ${ }^{72}$ But behaviours may lead to changed values if the benefit of change is clear. And the need for co-operative and productive workplace relations, supported by adequate legal rights protecting all stakeholders, should be obvious to and supported by all reasonable employers and employees.

I concluded the answer to my question was a qualified yes. The final point I would make is that this is not the case for all workers in all situations. Many workers, and particularly the most vulnerable, need more effective protection. Further legislative reform may improve their situation but there are limits to what can be achieved by statute. What is also needed is adequate enforcement of existing rights.

The most effective protection for employees is, and always has been, through collective organisation. Collective representation provides the strength for employees to influence their terms of employment, the strength to ensure some joint management of the relationship day to day, and most importantly the resources to effectively their enforce their rights.

But that is another lecture for another day.

72 Margaret Wilson "The Employment Relations Act: A Framework for a Fairer Way" in E Rasmussen (ed) Employment Relationships: New Zealand's Employment Relations Act (Auckland University Press, Auckland, 2004) 9, 17. 